\title{
Grain quality of common bean (Phaseolus vulgaris L.) cultivars under low and high nitrogen dose
}

\section{Calidad de grano de los cultivares de frijol (Phaseolus vulgaris L.) común sobre baja y alta dosis de nitrógeno}

Fábio Tiraboschi Leal * , João Victor Trombeta Bettiol, Vinícius Augusto Filla, Anderson Prates Coelho, Fábio Luíz Checchio Mingotte, Leandro Borges Lemos

Originales: Recepción: 30/03/2020 - Aceptación: 25/03/2021

\begin{abstract}
This study aimed to evaluate the effects of low and high topdressing doses of nitrogen $(\mathrm{N})$ on the qualitative attributes of common beans (Phaseolus vulgaris L.) cultivars and indicate cultivars with better grain technological characteristics. The experimental design was randomized blocks in split plots, with four replicates. Plots comprised 16 common bean cultivars of the commercial grain 'Carioca', while subplots comprised two N doses: 20 and $120 \mathrm{~kg} \mathrm{ha}^{-1}$ applied as topdressing. The following evaluations were carried out: sieve yield (SY), relative grain production on sieves (RGPS), crude protein content (PROT), final water volume absorbed (FVabs), time for maximum hydration (TMH), hydration ratio (HR), cooking time (CT) and resistance to cooking (RC). The results were subjected to analysis of variance by F test and means were grouped by the Scott-Knott test. Multivariate principal component analysis was used to identify processes. Grain quality of common bean resulted to be more dependent on the genotype studied than on the agricultural management, such as nitrogen fertilization. Increasing $\mathrm{N}$ dose applied as topdressing increased grain size and protein content, but had little influence on grain hydration. FVabs and CT depended on the interaction between cultivar and N doses. Although low value, CT had an inverse correlation with PROT. The cultivars BRSMG Uai, IAC Alvorada, TAA Dama and TAA Bola Cheia showed the best grain quality characteristics.
\end{abstract}

\section{Keywords}

nitrogen fertilization $\bullet$ genotypes $\bullet$ grain technology $\bullet$ cooking time $\bullet$ protein content

São Paulo State University (Unesp). School of Agricultural and Veterinarian Sciences. Department of Agricultural Sciences. Jaboticabal - 14884-900. São Paulo. Brazil.*lealft@bol.com.br 


\section{RESUMEN}

Este estudio tuvo como objetivo evaluar los efectos de la baja y alta dosis de nitrógeno (N) en cobertura sobre los atributos cualitativos de los cultivares de frijol común (Phaseolus vulgaris L.) e indicar los cultivares con mejores características tecnológicas de grano. El diseño experimental fue bloques al azar en parcelas divididas, con cuatro repeticiones. Las parcelas comprendían 16 cultivares de frijol común del grano comercial "Carioca", mientras que las subparcelas comprendían dos dosis de $\mathrm{N}: 20$ y $120 \mathrm{~kg} \mathrm{ha}^{-1}$ aplicados como cobertura. Se llevaron a cabo las siguientes evaluaciones: rendimiento del tamiz (SY), producción relativa de granos en tamices (RGPS), contenido de proteína cruda (PROT), volumen de agua final absorbido (FVabs), tiempo para la hidratación máxima (TMH), relación de hidratación (HR), tiempo de cocción (CT) y resistencia a la cocción (RC). Los resultados se sometieron a análisis de varianza mediante la prueba $\mathrm{F}$ y las medias se agruparon mediante la prueba de Scott-Knott. El análisis de componentes principales multivariante se utilizó para identificar procesos. La calidad del grano del frijol común depende más del genotipo estudiado que del manejo agrícola como la fertilización nitrogenada. El aumento en la dosis de $\mathrm{N}$ aplicada como topdressing aumenta el tamaño de los granos de frijol comunes y su contenido de proteínas, pero con poca influencia en la hidratación del grano. FVabs y CT dependen de la interacción entre cultivar y N dosis. CT tuvo una correlación inversa con PROT, pero fue poco pronunciada. Los cultivares BRSMG Uai, IAC Alvorada, TAA Dama y TAA Bola Cheia tienen las mejores características de calidad de grano.

\section{Palabras clave}

fertilización nitrogenada • genotipos • tecnología de granos • tiempo de cocción • contenido de proteínas

\section{INTRODUCTION}

Brazil is the largest global producer of common beans (Phaseolus vulgaris L.), with a cultivated area of approximately 3.2 million hectares (4). The most consumed commercial grain at national level is the 'Carioca' type. The grains of this leguminous plant stand out for their high nutritional value, due to the high contents of protein with good digestibility, essential amino acids, potassium and low levels of fat $(9,14)$.

Common bean genetic improvement programs have sought to develop and select cultivars with high production potentials and also good acceptance in the market. Interesting characteristics for consumers and packing industries include shorter cooking time, higher and faster hydration capacity, larger size and high protein contents in the grains $(14,17)$.

These qualitative attributes are influenced by the interaction between genotype and environment. Pereira et al. (2017) observed that the environmental effect is greater than the genotypic effect on the expression of characters related to grain technology. Nitrogen fertilization management can cause differences in these characteristics, which depend on the production system adopted $(5,7)$. These authors found that increments in topdressing nitrogen $(\mathrm{N})$ increased protein contents in common bean grains under both direct planting system and conventional soil tillage. However, cooking time showed different response patterns between the systems.

The relationships between grain qualitative attributes have not yet been well elucidated by the literature, and there are divergences of information. Pereira et al. (2017) and Mingotte et al. (2015) observed an inverse relationship between CT and protein content for some genotypes. Nonetheless, Farinelli and Lemos (2010) found increase in cooking time with the increment in protein content, for the conventional soil tillage system. Cooking time is affected by other factors which depend on genotypes, which makes it difficult to use the protein content for indirect selection of cultivars with shorter cooking time.

Given the above, it is necessary to conduct studies aiming to better understand the relationships between qualitative attributes and the influence of the environment on these grain characteristics. With the hypothesis that the genetic diversity among cultivars leads to differences in the grain quality and differentiated responses to topdressing $\mathrm{N}$ fertilization, 
the present study aimed to evaluate the effect of low and high topdressing $\mathrm{N}$ doses on the qualitative attributes of grains of common bean cultivars and indicate those with better grain technological characteristics.

\section{MATERIAL AND METHODS}

\section{Location, period and soil characterization}

The experiment was conducted in the agricultural year 2016/17 in Jaboticabal, Sao

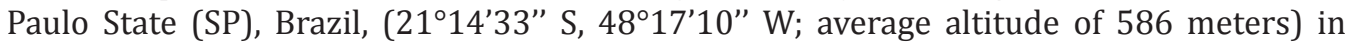
soil classified as Oxisol (Latossolo Vermelho eutroférrico), with clayey texture, on a gently undulating relief with 6\% slope. According to Köppen's classification, the climate of this region is Aw, humid tropical with rainy period in the summer and dry period in the winter.

The experimental area was in the first year of no-tillage system (NT) under millet ADR-300 (Pennisentum americanum L.) straw in the quantity of $5.1 \mathrm{t} \mathrm{ha}^{-1}$. The chemical attributes of soil fertility and particle size were determined in the $0-0.20 \mathrm{~m}$ layer prior to common bean sowing. The results were: $\mathrm{pH}\left(\mathrm{CaCl}_{2}\right) 6.0$; organic matter $(\mathrm{OM})=29 \mathrm{~g} \mathrm{dm}^{-3}$; $\mathrm{P}($ resin $)=50 \mathrm{mg} \mathrm{dm}^{-3} ; \mathrm{K}=6.4 \mathrm{mmol}_{\mathrm{c}} \mathrm{dm}^{-3} ; \mathrm{Ca}=33 \mathrm{mmol}_{\mathrm{c}} \mathrm{dm}^{-3} ; \mathrm{Mg}=14 \mathrm{mmol}_{\mathrm{c}} \mathrm{dm}^{-3}$; $\mathrm{S}=8 \mathrm{mg} \mathrm{dm}^{-3}, \mathrm{~B}=0.32 \mathrm{mg} \mathrm{dm}^{-3} ; \mathrm{Cu}=1.1 \mathrm{mg} \mathrm{dm}^{-3}, \mathrm{Fe}=14 \mathrm{mg} \mathrm{dm}^{-3}, \mathrm{Mn}=20.1 \mathrm{mg} \mathrm{dm}^{-3}$, $\mathrm{Zn}=4.0 \mathrm{mg} \mathrm{dm}^{-3}, \mathrm{H}+\mathrm{Al}=16 \mathrm{mmol} \mathrm{dm}_{\mathrm{c}}^{-3} ; \mathrm{CEC}=70 \mathrm{mmol}_{\mathrm{c}} \mathrm{dm}^{-3} ; \mathrm{V}=77 \%$, clay $=540 \mathrm{~g} \mathrm{~kg}^{-1}$; silt $=230 \mathrm{~g} \mathrm{~kg}^{-1}$ and sand $=230 \mathrm{~g} \mathrm{~kg}^{-1}$.

\section{Conduction, experimental design and treatments}

Common bean cultivars were manually sown under millet straw on June 8, 2017 at $0.45 \mathrm{~m}$ spacing between rows using 12 seeds per meter. Fertilization at sowing was applied using $210 \mathrm{~kg} \mathrm{ha}^{-1}$ of the formulation $04-20-20$ (5.1\% Ca, 4\% S, 0.05\% B, 0.06\% Mn and $0.27 \% \mathrm{Zn}$ ). Common bean plants were irrigated by a conventional sprinkler system with variable intervals according to crop requirements.

The experimental design was randomized blocks in split-plot scheme, with four replicates. Plots comprised 16 common beans cultivars of the commercial grain 'Carioca': ANFc 9, BRSMG Uai, BRS Estilo, BRSMG Madrepérola, Pérola, BRS FC402, IAC Alvorada, IAC Milênio, IAC Sintonia, IPR Andorinha, IPR Campos Gerais, IPR Curió, IPR Celeiro, IPR Maracanã, TAA Dama and TAA Bola Cheia. Subplots consisted of two levels of topdressing N fertilization: minimum level ( $\mathrm{N}$ dose of $20 \mathrm{~kg} \mathrm{ha}^{-1}$ ) and maximum level ( $\mathrm{N}$ dose of $120 \mathrm{~kg} \mathrm{ha}^{-1}$ ). Each plot had $22.5 \mathrm{~m}^{2}$ and was consisted by two subplots which was formed by five 5-m-long rows of common bean with rows spacing of $0.45 \mathrm{~m}$ and evaluations were carried out using the three central rows, disregarding $0.5 \mathrm{~m}$ on each side $\mathrm{N}$ doses were applied as topdressing at $\mathrm{V}_{4}$ stage (presence of third trifoliate leaf) in continuous strip at $0.10 \mathrm{~m}$ away from the planting row, using coated urea as source, followed by irrigation with $20 \mathrm{~mm}$ water depth for incorporation.

\section{Grain quality evaluations}

After harvest, grain quality evaluations were carried out. To determine sieve yield (SY), grain samples were subjected to the set of sieves with oblong holes, in agitation for one minute, with oblong holes of $19.05 \mathrm{~mm}$ of major axis and the following minor axes size: $4.37 \mathrm{~mm}$ (S11); $4.76 \mathrm{~mm}$ (S12); $5.16 \mathrm{~mm}$ (S13); $5.56 \mathrm{~mm}$ (S14) and $5.96 \mathrm{~mm}$ (S15). The percentage of grains was calculated by the relationship between the mass of grains retained on each sieve and the total mass of the sample from each subplot. SY was given by the sum of the percentages of grains retained on sieves with holes larger than or equal to 12 . These results were used to calculate the relative grain production on sieves (RGPS) according to the adaptation of the methodology of Carbonell et al. (2010), which establishes weights for the sieves. According to Carbonell et al. (2010), the notes for each sieve were defined based on the requirement of the packaging industry and the consumer market. For this definition of banknotes, the main packers in the State of São Paulo, Brazil, were visited to check which is the best type of grain depending on its size (sieve yield). In the present study, the weight 1 was considered for grains retained on the collector $(S \leq 10$, i.e., smaller than or equal to 10). S10 had oblong holes of $19,05 \mathrm{~mm}$ at major axis and $3.96 \mathrm{~mm}$ at minor axis. 
RGPS was obtained using the following equation:

$$
\text { RGPS }=\frac{(\mathrm{S} \leq 10 \times 1)+(\mathrm{S} 11 \times 4)+(\mathrm{S} 12 \times 6)+(\mathrm{S} 13 \times 10)+(\mathrm{S} 14 \times 10)+(\mathrm{S} 15 \times 6)}{\mathrm{S} \leq 10+\mathrm{S} 11+\mathrm{S} 12+\mathrm{S} 13+\mathrm{S} 14+\mathrm{S} 15}
$$

Crude protein content (PROT) $\left(\mathrm{g} \mathrm{kg}^{-1}\right)$ was determined by the equation: $\mathrm{PROT}=$ Total $\mathrm{N}$ x 6.25 (2), in which Total $N$ represents the total $N$ content in the grains from each subplot, obtained by sulfuric digestion. Samples for PROT determination came from the grains of five plants consecutively collected along the row, at physiological maturity. The other evaluations used grains retained on the S13. Grain hydration capacity was determined using a $500-\mathrm{mL}$ graduated cylinder with precision of $5 \mathrm{~mL}$ and $250-\mathrm{mL}$ beakers. Each beaker received a $50-\mathrm{g}$ sample of previously selected grains and then $200 \mathrm{~mL}$ of distilled water. Every two hours, over a period of 16 hours, the volume of water not absorbed by the grains was evaluated, by pouring it from the beaker to the graduated cylinder. At the end of the expected time for hydration, excess water was drained and grains were weighed. Hydration ratio (HR) was determined by the ratio between final mass and initial mass of grains. Analysis of polynomial regression between time (hours) and hydration capacity $(\mathrm{mL})$ was carried out to determine the time required for maximum hydration (TMH) of common bean grains. Along the test, water temperature was $25^{\circ} \mathrm{C}$. The final water volume absorbed (FVabs) was given by the difference between the final and initial volumes measured in the TMH evaluation.

To determine the cooking time (CT) in minutes, common bean grains were subjected to Mattson cooker, which basically consists of 25 vertical plungers. The tip touches the grain during cooking and when it is cooked the tip penetrates it, hence displacing the plunger. The final time for cooking of the sample was obtained when $50 \%+1$, i.e., 13 plungers had been displaced. For this determination, grains were hydrated in distilled water for a 12-h period. During the test, water temperature was $96^{\circ} \mathrm{C}$. The scale of Proctor and Watts (1987) was adopted to verify the level of resistance to cooking.

\section{Statistical analysis of the data}

The data were subjected to analysis of variance by F test and means were grouped by the Scott-Knott test. When F was significant for the interaction between $\mathrm{N}$ doses and cultivar, it was further analyzed. Due to the dependency structure contained in the original set of variables, the data were submitted to multivariate analysis of principal components (PCs), which made it possible to project all the information contained in the original variables into new latent variables, which were the processes (7). Data were standardized, showing null mean and unit variance. The number of PCs was selected based on Kaiser's criterion, using those with eigenvalues above 1 (7).

\section{RESULTS AND DISCUSSION}

The percentage of grains retained on the sieves S11 to S15 was significantly influenced by the factors cultivar and $\mathrm{N}$ dose, except S12, for which the percentage was not affected by the increment of the nutrient (table 1, page 122). For S15, there was interaction between cultivar and $\mathrm{N}$ dose. The $\mathrm{N}$ dose of $20 \mathrm{~kg} \mathrm{ha}^{-1}$ led to higher percentages on S11 and S13, whereas $\mathrm{N}$ application of $120 \mathrm{~kg} \mathrm{ha}^{-1}$ resulted in higher percentage on S14 and S15.

The highest percentages on S11 were obtained for BRS FC402, IPR Curió, IPR Celeiro and IPR Maracanã, followed by BRSMG Madrepérola, IAC Milênio, IAC Sintonia and IPR Campos Gerais. The cultivars BRS FC402, IPR Curió, IPR Celeiro, BRSMG Madrepérola and IPR Maracanã also had higher percentages on S12. The genotypes BRSMG Madrepérola, BRS FC402 and IAC Sintonia had the largest amounts of grains retained on S13. On the other hand, the genetic materials with highest percentages on S14 were IPR Andorinha, TAA Dama and TAA Bola Cheia, followed by ANFc9, IAC Alvorada and IAC Milênio. For S15, at the lowest $\mathrm{N}$ dose, superiority was found for the cultivars IAC Alvorada, ANFC 9 and TAA Dama, whereas at $\mathrm{N}$ dose of $120 \mathrm{~kg} \mathrm{ha}^{-1}$ the cultivars IAC Alvorada, followed by ANFc9, stood out. The cultivars ANFc9, BRSMG Uai, Pérola, IAC Milênio, IPR Campos Gerais and TAA Bola Cheia showed increased percentages of grains retained on S15 with the increment in N dose. 
Table 1. Percentages of grains retained on the processing sieves $\mathrm{S} 11$ (4.37 $\mathrm{mm}), \mathrm{S} 12$ (4.76 mm), S13 (5.16 mm), S14 $(5.56 \mathrm{~mm})$ and S15 $(5.96 \mathrm{~mm})$ as a function of cultivars and nitrogen $(\mathrm{N})$ doses applied as topdressing.

Tabla 1. Porcentajes de granos retenidos en los tamices de procesamiento $\mathrm{S} 11$ (4,37 mm), $\mathrm{S} 12(4,76 \mathrm{~mm}), \mathrm{S} 13(5,16 \mathrm{~mm}), \mathrm{S} 14(5,56 \mathrm{~mm})$ and S15 (5,96 mm) en función de los cultivares y las dosis de nitrógeno $(\mathrm{N})$ aplicadas como cobertura.

\begin{tabular}{|c|c|c|c|c|c|c|}
\hline \multirow{2}{*}{ Cultivars } & \multirow{2}{*}{ S11 (\%) } & \multirow{2}{*}{ S12 (\%) } & \multirow{2}{*}{ S13 (\%) } & \multirow{2}{*}{ S14 (\%) } & \multicolumn{2}{|c|}{ S15 (\%) } \\
\hline & & & & & N20 & N120 \\
\hline ANFc 9 & $4.2 \mathrm{c}$ & $12.6 \mathrm{~d}$ & $27.7 \mathrm{e}$ & $38.9 \mathrm{~b}$ & $10.0 \mathrm{bB}$ & $13.3 \mathrm{bA}$ \\
\hline BRSMG Uai & $3.6 \mathrm{c}$ & $15.6 \mathrm{c}$ & $47.2 \mathrm{c}$ & $25.7 \mathrm{c}$ & $3.0 \mathrm{~dB}$ & $4.8 \mathrm{eA}$ \\
\hline BRS Estilo & $6.0 \mathrm{~b}$ & $18.1 \mathrm{c}$ & $47.6 \mathrm{c}$ & $21.0 \mathrm{~d}$ & $2.3 \mathrm{dA}$ & $1.4 \mathrm{fA}$ \\
\hline BRSMG Madrepérola & $6.0 \mathrm{~b}$ & $23.1 \mathrm{~b}$ & $58.1 \mathrm{a}$ & $8.3 \mathrm{e}$ & $0.6 \mathrm{eA}$ & $0.9 \mathrm{fA}$ \\
\hline Pérola & $4.8 \mathrm{~b}$ & $16.3 \mathrm{c}$ & $38.1 \mathrm{~d}$ & $30.4 \mathrm{~b}$ & $2.3 \mathrm{~dB}$ & $4.9 \mathrm{eA}$ \\
\hline BRS FC402 & $9.1 \mathrm{a}$ & $27.8 \mathrm{a}$ & $53.8 \mathrm{~b}$ & $3.9 \mathrm{e}$ & $0.2 \mathrm{eA}$ & $0.2 \mathrm{fA}$ \\
\hline IAC Alvorada & $4.4 \mathrm{c}$ & $14.5 \mathrm{c}$ & $29.0 \mathrm{e}$ & $33.3 \mathrm{~b}$ & $15.2 \mathrm{aA}$ & $16.5 \mathrm{aA}$ \\
\hline IAC Milênio & $4.9 \mathrm{~b}$ & $15.6 \mathrm{c}$ & $32.9 \mathrm{~d}$ & $36.1 \mathrm{~b}$ & $5.5 \mathrm{cB}$ & $7.7 \mathrm{dA}$ \\
\hline IAC Sintonia & $6.2 \mathrm{~b}$ & $19.4 \mathrm{c}$ & $51.3 \mathrm{~b}$ & $17.5 \mathrm{~d}$ & $1.1 \mathrm{eA}$ & $1.3 \mathrm{fA}$ \\
\hline IPR Andorinha & $3.2 \mathrm{c}$ & $13.3 \mathrm{~d}$ & $34.5 \mathrm{~d}$ & $42.5 \mathrm{a}$ & $3.9 \mathrm{dA}$ & $4.4 \mathrm{eA}$ \\
\hline IPR Campos Gerais & $5.4 \mathrm{~b}$ & $18.2 \mathrm{c}$ & $42.9 \mathrm{c}$ & $25.7 \mathrm{c}$ & $1.4 \mathrm{eB}$ & $3.0 \mathrm{eA}$ \\
\hline IPR Curió & $9.9 \mathrm{a}$ & $29.3 \mathrm{a}$ & $44.4 \mathrm{c}$ & $9.0 \mathrm{e}$ & $0.6 \mathrm{eA}$ & $0.9 \mathrm{fA}$ \\
\hline IPR Celeiro & $9.2 \mathrm{a}$ & $28.4 \mathrm{a}$ & $49.7 \mathrm{~b}$ & $6.7 \mathrm{e}$ & $0.5 \mathrm{eA}$ & $1.4 \mathrm{fA}$ \\
\hline IPR Maracanã & $9.0 \mathrm{a}$ & $24.2 \mathrm{~b}$ & $42.9 \mathrm{c}$ & $16.9 \mathrm{~d}$ & $2.9 \mathrm{dA}$ & $4.0 \mathrm{eA}$ \\
\hline TAA Dama & $2.8 \mathrm{c}$ & $9.8 \mathrm{e}$ & $25.5 \mathrm{e}$ & $48.4 \mathrm{a}$ & $9.2 \mathrm{bA}$ & $10.4 \mathrm{cA}$ \\
\hline TAA Bola Cheia & $2.5 \mathrm{c}$ & $9.2 \mathrm{e}$ & $26.2 \mathrm{e}$ & $48.2 \mathrm{a}$ & $9.1 \mathrm{bB}$ & $11.0 \mathrm{cA}$ \\
\hline $\mathrm{CV} \%-\mathrm{C}$ & 29.01 & 19.93 & 14.32 & 26.36 & \multicolumn{2}{|c|}{45.75} \\
\hline \multicolumn{7}{|c|}{$\mathrm{N}$ doses $\left(\mathrm{kg} \mathrm{ha}^{-1}\right)$} \\
\hline $\mathrm{N} 20$ & $6.0 \mathrm{a}$ & $18.7 \mathrm{a}$ & $42.5 \mathrm{a}$ & $24.2 \mathrm{~b}$ & \multicolumn{2}{|c|}{$4.2 \mathrm{~b}$} \\
\hline N120 & $5.4 \mathrm{~b}$ & $18.2 \mathrm{a}$ & $39.0 \mathrm{~b}$ & $27.4 \mathrm{a}$ & \multicolumn{2}{|c|}{$5.4 \mathrm{a}$} \\
\hline CV\% - N & 26.12 & 18.35 & 11.76 & 21.88 & \multicolumn{2}{|c|}{22.90} \\
\hline \multicolumn{7}{|c|}{ F test } \\
\hline Cultivar (C) & $16.91^{* *}$ & $24.39^{* *}$ & $25.60^{* *}$ & $37.60^{* *}$ & \multicolumn{2}{|c|}{$35.83^{* *}$} \\
\hline $\mathrm{N}$ dose $(\mathrm{N})$ & $4.27^{*}$ & $0.64^{\mathrm{NS}}$ & $17.30^{* *}$ & $10.57^{* *}$ & \multicolumn{2}{|c|}{$35.30^{* *}$} \\
\hline $\mathrm{CXN}$ & $0.61^{\mathrm{NS}}$ & $1.00^{\mathrm{NS}}$ & $0.90^{\mathrm{NS}}$ & $1.22^{\mathrm{NS}}$ & \multicolumn{2}{|c|}{$1.92^{*}$} \\
\hline
\end{tabular}

Means followed by different letters, lowercase in columns and uppercase in rows, differ by Scott-Knott test at 0.05 probability level. NS Not significant by F test. ** Significant by F test $(\mathrm{p}<0.01)$. ${ }^{*}$ Significant by F test $(\mathrm{p}<0.05)$.

Las medias seguidas de diferentes letras, minúsculas en columnas y mayúsculas en filas, difieren según la prueba de Scott-Knott con un nivel de probabilidad de 0,05 . NS No significativo por la prueba F. ** Significativo por prueba $F(p<0,01)$. Significativo por prueba $F(p<0,05)$.

As a consequence of the highest percentages on S14, the cultivars with highest SY were ANFc 9, BRSMG Uai, BRSMG Madrepérola, IAC Alvorada, IAC Milênio, IPR Andorinha, TAA Dama and TAA Bola Cheia.

However, it is important to emphasize that all cultivars had SY above 70\%, a reference value for packing industries to pay a bonus to the producer because the grains are large and with good acceptance in the market (3). The genotypes with highest levels of RGPS were ANFc 9, BRSMG Uai, BRS Estilo, BRSMG Madrepérola, Pérola, IAC Alvorada, IAC Milênio, IAC Sintonia, IPR Andorinha, IPR Maracanã, TAA Dama and TAA Bola Cheia. The means of RGPS for all genotypes were above 7, the value proposed by Carbonell et al. (2010) as grains of good acceptance in the market and packing industries. These results are interesting because they demonstrate the concern of genetic improvement programs about developing cultivars with larger grains. SY and RGPS were not significantly affected by N doses (table 2, page 123). The lack of significant difference for these variables is due to the fact that the $\mathrm{N}$ dose of $20 \mathrm{~kg} \mathrm{ha}^{-1}$ led to higher percentages on S13 compared to S14. Both sieves are superior to S12 and have the same weight in the calculation of RGPS. 
Table 2. Sieve yield (SY), relative grain production on sieves (RGPS), crude protein content (PROT) and final water volume absorbed (FVabs) as a function of the cultivars and nitrogen $(\mathrm{N})$ doses applied as topdressing.

Tabla 2. Rendimiento del tamiz (SY), producción relativa de granos en tamices (RGPS), contenido de proteína cruda (PROT) y volumen de agua final absorbido (FVabs) en función de los cultivares y las dosis de nitrógeno (N) aplicadas como cobertura.

\begin{tabular}{|c|c|c|c|c|c|}
\hline Cultivars & SY (\%) & RGPS & PROT (\%) & \multicolumn{2}{|c|}{ FVabs (mL) } \\
\hline ANFc 9 & $90.9 \mathrm{a}$ & $8.3 \mathrm{a}$ & $18.2 \mathrm{a}$ & $68.7 \mathrm{bA}$ & $71.2 \mathrm{bA}$ \\
\hline BRSMG Uai & $92.3 \mathrm{a}$ & $8.7 \mathrm{a}$ & $16.9 \mathrm{a}$ & $72.5 \mathrm{aA}$ & $75.0 \mathrm{aA}$ \\
\hline BRS Estilo & 88.5 b & $8.4 \mathrm{a}$ & $16.4 \mathrm{~b}$ & $68.7 \mathrm{bA}$ & $73.7 \mathrm{aA}$ \\
\hline BRSMG Madrepérola & $90.3 \mathrm{a}$ & $8.3 \mathrm{a}$ & $18.4 \mathrm{a}$ & $67.5 \mathrm{bA}$ & $67.5 \mathrm{bA}$ \\
\hline Pérola & $88.4 \mathrm{~b}$ & $8.3 \mathrm{a}$ & $16.8 \mathrm{~b}$ & $70.0 \mathrm{bA}$ & $68.7 \mathrm{bA}$ \\
\hline BRS FC402 & $85.6 \mathrm{c}$ & $7.9 \mathrm{~b}$ & $16.3 \mathrm{~b}$ & $67.5 \mathrm{bA}$ & $68.7 \mathrm{bA}$ \\
\hline IAC Alvorada & $92.7 \mathrm{a}$ & $8.2 \mathrm{a}$ & $17.8 \mathrm{a}$ & $67.5 \mathrm{bA}$ & $70.0 \mathrm{bA}$ \\
\hline IAC Milênio & $91.1 \mathrm{a}$ & $8.5 \mathrm{a}$ & $15.9 \mathrm{~b}$ & $70.0 \mathrm{bA}$ & $68.7 \mathrm{bA}$ \\
\hline IAC Sintonia & $89.3 \mathrm{~b}$ & $8.4 \mathrm{a}$ & $14.7 \mathrm{~b}$ & $70.0 \mathrm{bA}$ & $65.0 \mathrm{bA}$ \\
\hline IPR Andorinha & $94.4 \mathrm{a}$ & $8.9 \mathrm{a}$ & $16.6 \mathrm{~b}$ & $66.2 \mathrm{bA}$ & $66.2 \mathrm{bA}$ \\
\hline IPR Campos Gerais & $89.2 \mathrm{~b}$ & $8.1 \mathrm{~b}$ & $15.9 \mathrm{~b}$ & $75.0 \mathrm{aA}$ & $67.5 \mathrm{bB}$ \\
\hline IPR Curió & $83.5 \mathrm{c}$ & $7.7 \mathrm{~b}$ & $17.8 \mathrm{a}$ & $73.7 \mathrm{aA}$ & $72.5 \mathrm{aA}$ \\
\hline IPR Celeiro & $85.7 \mathrm{c}$ & $7.8 \mathrm{~b}$ & $17.1 \mathrm{a}$ & $72.5 \mathrm{aA}$ & $73.7 \mathrm{aA}$ \\
\hline IPR Maracanã & $87.5 \mathrm{~b}$ & $8.5 \mathrm{a}$ & $17.3 \mathrm{a}$ & $73.7 \mathrm{aB}$ & $80.0 \mathrm{aA}$ \\
\hline TAA Dama & $93.5 \mathrm{a}$ & $8.7 \mathrm{a}$ & $17.9 \mathrm{a}$ & $71.2 \mathrm{bA}$ & $76.2 \mathrm{aA}$ \\
\hline TAA Bola Cheia & $93.8 \mathrm{a}$ & $8.7 \mathrm{a}$ & $17.4 \mathrm{a}$ & $77.5 \mathrm{aA}$ & $75.0 \mathrm{aA}$ \\
\hline $\mathrm{CV} \%-\mathrm{C}$ & 3.65 & 5.65 & 9.14 & \multicolumn{2}{|c|}{5.00} \\
\hline \multicolumn{6}{|c|}{$\mathrm{N}$ doses $\left(\mathrm{kg} \mathrm{ha}^{-1}\right)$} \\
\hline $\mathrm{N} 20$ & $89.6 \mathrm{a}$ & $8.3 \mathrm{a}$ & $16.7 \mathrm{~b}$ & \multicolumn{2}{|c|}{$70.8 \mathrm{a}$} \\
\hline N120 & $90.0 \mathrm{a}$ & $8.3 \mathrm{a}$ & $17.3 \mathrm{a}$ & \multicolumn{2}{|c|}{$71.2 \mathrm{a}$} \\
\hline CV\% - N & 3.37 & 5.26 & 8.05 & \multicolumn{2}{|c|}{5.26} \\
\hline \multicolumn{6}{|c|}{ F test } \\
\hline Cultivar (C) & $7.45^{* *}$ & $4.33^{* *}$ & $3.13^{* *}$ & \multicolumn{2}{|c|}{$6.47^{* *}$} \\
\hline $\mathrm{N}$ dose $(\mathrm{N})$ & $0.55^{\mathrm{NS}}$ & $0.01^{\mathrm{NS}}$ & $5.72^{*}$ & \multicolumn{2}{|c|}{$0.50^{\mathrm{NS}}$} \\
\hline $\mathrm{CXN}$ & $0.89^{\mathrm{NS}}$ & $1.16^{\mathrm{NS}}$ & $1.09^{\mathrm{NS}}$ & \multicolumn{2}{|c|}{$1.91^{*}$} \\
\hline
\end{tabular}

Means followed by different letters, lowercase in columns and uppercase in rows, differ by Scott-Knott test at 0.05 probability level. NS Not significant by F test. ${ }^{* *}$ Significant by F test $(\mathrm{p}<0.01)$. ${ }^{*}$ Significant by F test $(\mathrm{p}<0.05)$.

Las medias seguidas de diferentes letras, minúsculas en columnas y mayúsculas en filas, difieren según la prueba de Scott-Knott con un nivel de probabilidad de 0,05. NS No significativo por la prueba F. ** Significativo por prueba $F(p<0,01)$. ${ }^{*}$ Significativo por prueba $F(p<0,05)$.

Crude protein contents increased with the $\mathrm{N}$ dose of $120 \mathrm{~kg} \mathrm{ha}^{-1}$ as topdressing. After being absorbed, $\mathrm{N}$ associates with organic compounds, giving rise to proteins, which result in increase of grain weight $(1,13)$ and, consequently, increments in grain size.

The highest percentages were observed for ANFc 9, BRS MG Uai, BRSMG Madrepérola, IAC Alvorada, IPR Curió, IPR Celeiro, IPR Maracanã, TAA Dama and Bola Cheia. Protein contents varied from 14.7 to $18.4 \%$ (table 2). These values were below the mean contents of 20.2\%, 21.6\% and 20.3\% found by Farinelli and Lemos (2010), Mingotte et al. (2015) and Miano et al. (2018), which is explained by the higher doses and splitting of topdressing $\mathrm{N}$ adopted in these studies.

FVabs was significantly influenced by the interaction between dose and cultivar. The grains which most absorbed water, under the lowest N dose, were those of BRSMG Uai, IPR Campos Gerais, IPR Curió, IPR Celeiro, IPR Maracanã and TAA Bola Cheia. Under the highest $\mathrm{N}$ dose, the largest volumes absorbed were found for BRSMG Uai, BRS Estilo, IPR Curió, IPR Celeiro, IPR Maracanã, TAA Dama and TAA Bola Cheia. With the increment in N, water absorption capacity decreased by $7.5 \mathrm{~mL}$ per $50 \mathrm{~g}$ of common bean in the cultivar IPR Campos Gerais and increased by $6.7 \mathrm{~mL}$ in IPR Maracanã.

Based on multivariate analysis of principal component (PCs) (figure 1, page 124), it can be observed that the first two PCs were responsible for $62.1 \%$ of the total data variability. 


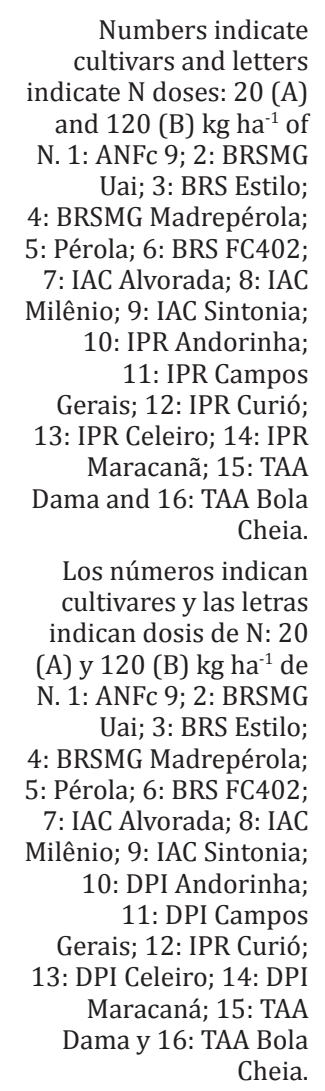

Numbers indicate dicate $\mathrm{N}$ doses: $20(\mathrm{~A})$ and 120 (B) kg ha-1 of Uai; 3: BRS Estilo; 4: BRSMG Madrepérola; 5: Pérola; 6: BRS FC402;

7: IAC Alvorada; 8: IAC 0: IPR Andorinha; 11: IPR Campos Gerais; 12: IPR Curió;

Maracana; 15: TAA Bola Cheia.

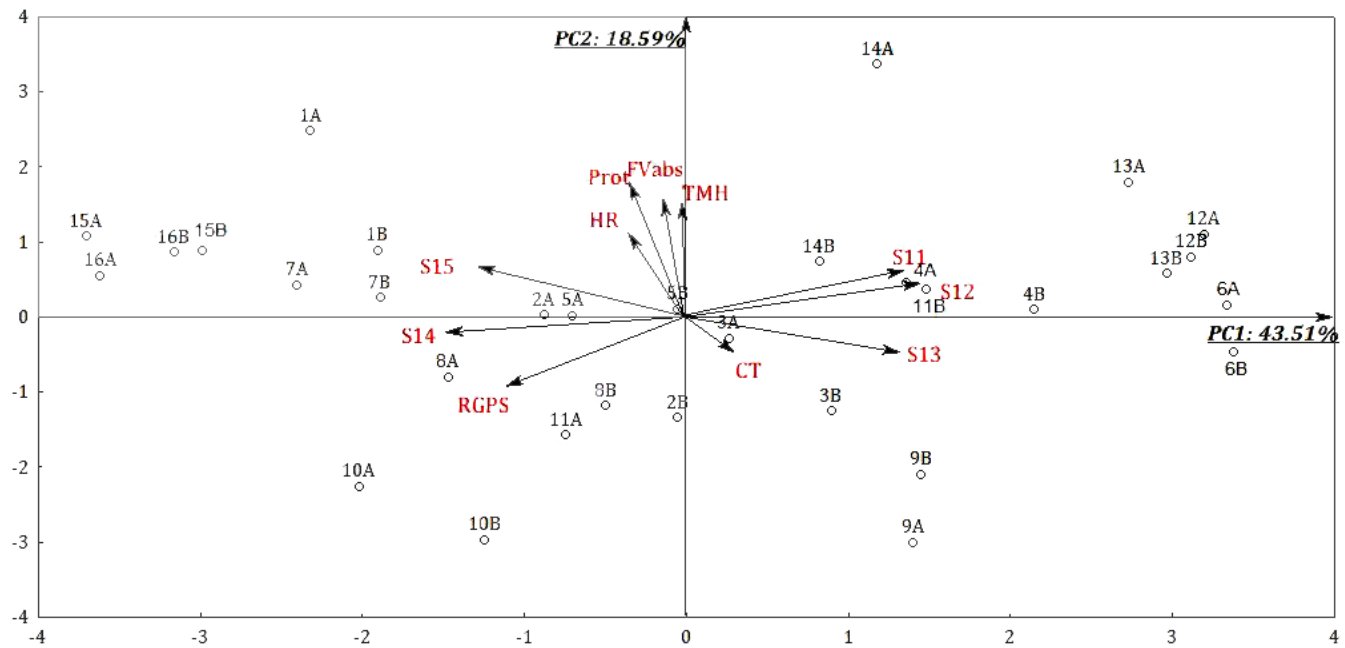

Figure 1. Biplot graph of the principal components for the distribution of common bean cultivars under nitrogen $(\mathrm{N})$ doses as a function of grain technological variables.

Figura 1. Gráfico biplot de los componentes principales para la distribución de cultivares de frijol común sobre baja dosis de nitrógeno $(\mathrm{N})$ en función de las variables tecnológicas del grano.

The variables which most discriminated PC1 were those related to the distribution of grains on the sieves. The high factorial scores of S11 (0.89), S12 (0.96), S13 (0.87), S14 $(-0.97)$, S15 (-0.83) and RGPS (-0.72) with PC1 allowed the genotypes to be separated by grain size. An analysis of the biplot graph allows observing a positive correlation between the sieves with smallest holes (S11 to S13) and a negative correlation between these and the sieves with largest holes (S14 and S15). The variables with highest correlations with PC2 were protein content (0.75), FVabs (0.67) and TMH (0.63).

TMH was significantly affected only by the cultivars (table 3, page 125). The highest TMH was obtained for ANFc 9, which required 15 hours and 50 minutes for its maximum hydration. The common bean grains with fastest hydration were those of BRSMG Uai, BRS Estilo, IAC Alvorada, IAC Sintonia, IPR Andorinha and IPR Campos Gerais, varying from 11 hours and 54 minutes to 12 hours and 18 minutes. The results obtained for these materials, close to 12 hours, were satisfactory, since consumers usually subject common bean grains to soaking the night prior to cooking $(5,10)$.

HR values were higher for ANFc 9, BRSMG Uai, BRS Estilo, BRSMG Madrepérola, Pérola, IAC Alvorada, IPR Campos Gerais, IPR Celeiro, IPR Maracanã, TAA Dama and TAA Bola Cheia (table 3, page 125). Although the differences were significant between the cultivars, it is important to point out that all values were close to 2 . These results corroborate those of Farinelli and Lemos (2010), who observed that common bean grains were able to absorb, in mass of water, approximately the equivalent to their initial masses. The increment of $\mathrm{N}$ via topdressing fertilization did not increase HR. Although the highest $\mathrm{N}$ dose increased protein content in the grains, the difference between fertilization managements was minimal $(0.6 \%)$. Even though the protein is hydrophilic (5), with high water absorption capacity, this difference was not sufficient to increase TMH and HR under high $\mathrm{N}$ dose. In addition, the different proteins present in common bean grains have different levels of hydrophilicity, varying according to the genotype (11). Miano et al. (2018) cite that common bean hydration kinetics depends on other genetic factors, such as fat content, starch content, specific surface and morphological aspects of the grain. 
Table 3: Time for maximum hydration (TMH), hydration ratio (HR), cooking time (CT) and resistance to cooking (RC) of common bean grains as a function of the cultivars and $\mathrm{N}$ doses applied as topdressing.

Table 3: Tiempo para la hidratación máxima (TMH), relación de hidratación (HR), tiempo de cocción (CT) y resistencia a la cocción (RC) de los granos de frijol común en función de los cultivares y dosis de $\mathrm{N}$ aplicadas como cobertura.

Means followed by different letters, lowercase in columns and uppercase in rows, differ by Scott-Knott test at 0.05 probability level. ${ }^{\text {NS }}$ Not significant by $\mathrm{F}$ test. ${ }^{* *}$ Significant by $\mathrm{F}$ test $(\mathrm{p}<0.01)$.

* Significant by $\mathrm{F}$ test $(\mathrm{p}<0.05)$. NR: Normal resistance; MS: Medium susceptibility.

Las medias seguidas de diferentes letras, minúsculas en columnas y mayúsculas en

filas, difieren según

la prueba de Scott-

Knott con un nivel de probabilidad de 0,05 . ${ }^{\mathrm{NS}}$ No significativo por la prueba F. ${ }^{* *}$ Significativo por prueba $\mathrm{F}$

$(\mathrm{p}<0,01) .{ }^{*}$ Significativo por prueba $\mathrm{F}(\mathrm{p}<0,05)$. NR: Resistencia normal;

MS: Susceptibilidad media.

\begin{tabular}{|c|c|c|c|c|c|c|}
\hline \multirow{2}{*}{ Cultivars } & \multirow{2}{*}{$\begin{array}{c}\text { TMH } \\
\text { (hh:mm) }\end{array}$} & \multirow{2}{*}{ HR } & \multicolumn{2}{|c|}{ CT (mm:ss) } & \multicolumn{2}{|c|}{ RC } \\
\hline & & & N20 & N120 & N20 & N120 \\
\hline ANFc 9 & $15: 50 \mathrm{a}$ & $2.00 \mathrm{a}$ & $21: 56 \mathrm{aB}$ & $24: 32$ aA & NR & NR \\
\hline BRSMG Uai & $11: 54 \mathrm{c}$ & $2.03 \mathrm{a}$ & $23: 37 \mathrm{aB}$ & $26: 45$ aA & NR & NR \\
\hline BRS Estilo & $11: 55 \mathrm{c}$ & $2.01 \mathrm{a}$ & $17: 47 \mathrm{bB}$ & $22: 12 \mathrm{bA}$ & MS & NR \\
\hline BRSMG Madrepérola & $13: 16 \mathrm{~b}$ & $2.02 \mathrm{a}$ & $21: 09 \mathrm{aA}$ & $21: 11 \mathrm{bA}$ & $\mathrm{NR}$ & NR \\
\hline Pérola & $13: 45 \mathrm{~b}$ & $2.02 \mathrm{a}$ & $21: 36 \mathrm{aA}$ & $21: 45 \mathrm{bA}$ & NR & NR \\
\hline BRS FC402 & $13: 40 \mathrm{~b}$ & $1.98 \mathrm{~b}$ & $21: 37$ aA & $22: 27 \mathrm{bA}$ & NR & NR \\
\hline IAC Alvorada & $11: 48 \mathrm{c}$ & $2.02 \mathrm{a}$ & $19: 50 \mathrm{aA}$ & $19: 07 \mathrm{cA}$ & MS & MS \\
\hline IAC Milênio & $13: 07 \mathrm{~b}$ & $1.98 \mathrm{~b}$ & $21: 21 \mathrm{aA}$ & $20: 26 \mathrm{cA}$ & NR & NR \\
\hline IAC Sintonia & $12: 01 \mathrm{c}$ & $1.97 \mathrm{~b}$ & $21: 53 \mathrm{aA}$ & $21: 16 \mathrm{bA}$ & NR & NR \\
\hline IPR Andorinha & $11: 58 \mathrm{c}$ & $1.93 \mathrm{c}$ & $20: 10 \mathrm{aA}$ & $20: 22 \mathrm{cA}$ & NR & NR \\
\hline IPR Campos Gerais & $12: 18 \mathrm{c}$ & $2.00 \mathrm{a}$ & $17: 16 \mathrm{bA}$ & $16: 32 \mathrm{dA}$ & MS & MS \\
\hline IPR Curió & $13: 11 \mathrm{~b}$ & $1.95 \mathrm{c}$ & $19: 54 \mathrm{aB}$ & $23: 17 \mathrm{bA}$ & MS & NR \\
\hline IPR Celeiro & $13: 02 \mathrm{~b}$ & $2.01 \mathrm{a}$ & $21: 06 \mathrm{aA}$ & $19: 07 \mathrm{cA}$ & NR & MS \\
\hline IPR Maracanã & $14: 06 \mathrm{~b}$ & $2.03 \mathrm{a}$ & $18: 22 \mathrm{bA}$ & $16: 57 \mathrm{dA}$ & MS & MS \\
\hline TAA Dama & $13: 23 \mathrm{~b}$ & $2.02 \mathrm{a}$ & $17: 58 \mathrm{bA}$ & $18: 29 \mathrm{cA}$ & MS & MS \\
\hline TAA Bola Cheia & $12: 56 \mathrm{~b}$ & $2.01 \mathrm{a}$ & $17: 52 \mathrm{bA}$ & $18: 29 \mathrm{cA}$ & MS & MS \\
\hline $\mathrm{CV} \%-\mathrm{C}$ & 9.17 & 0.96 & \multicolumn{2}{|c|}{8.26} & \multicolumn{2}{|c|}{-} \\
\hline \multicolumn{7}{|c|}{$\mathrm{N}$ doses $\left(\mathrm{kg} \mathrm{ha}^{-1}\right)$} \\
\hline $\mathrm{N} 20$ & $13: 00 \mathrm{a}$ & $1.99 \mathrm{a}$ & \multicolumn{2}{|c|}{$20: 48 a$} & \multicolumn{2}{|c|}{ MS } \\
\hline N120 & $13: 01 \mathrm{a}$ & $2.00 \mathrm{a}$ & \multicolumn{2}{|c|}{$20: 13$ a } & \multicolumn{2}{|c|}{ MS } \\
\hline $\mathrm{CV} \%-\mathrm{N}$ & 5.39 & 0.86 & \multicolumn{2}{|c|}{8.18} & \multicolumn{2}{|c|}{ 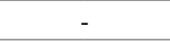 } \\
\hline \multicolumn{7}{|c|}{ F test } \\
\hline Cultivar (C) & $6.29^{* *}$ & $18.72^{* *}$ & \multicolumn{2}{|c|}{$12.83^{* *}$} & \multicolumn{2}{|c|}{-} \\
\hline $\mathrm{N}$ dose $(\mathrm{N})$ & $0.08^{\mathrm{NS}}$ & $2.46^{\mathrm{NS}}$ & \multicolumn{2}{|c|}{$4.00^{\mathrm{NS}}$} & \multicolumn{2}{|c|}{ - } \\
\hline $\mathrm{CXN}$ & $0.81^{\mathrm{NS}}$ & $1.28^{\mathrm{NS}}$ & \multicolumn{2}{|c|}{$2.43^{*}$} & \multicolumn{2}{|c|}{-} \\
\hline
\end{tabular}

CT was significantly influenced by the cultivar and by the interaction between cultivar and dose (table 3). The lowest values of CT were obtained under the $\mathrm{N}$ dose of $20 \mathrm{~kg} \mathrm{ha}^{-1}$, for BRS Estilo, IPR Campos Gerais, IPR Maracanã, TAA Dama and TAA Bola Cheia. Under the highest $\mathrm{N}$ dose, the cultivars whose grains were cooked in the shortest time were IPR Campos Gerais and IPR Maracanã, followed by IAC Alvorada, IAC Milênio, IPR Andorinha, IPR Celeiro, TAA Dama and TAA Bola Cheia. In the genotypes ANFc 9, BRSMG Uai, BRS Estilo and IPR Curió, CT increased significantly with the increment in $\mathrm{N}$ dose.

According to the scale of Proctor and Watts (1987), the grains of the cultivars IAC Alvorada, IPR Campos Gerais, IPR Maracanã, TAA Dama and TAA Bola Cheia are grouped as materials of medium susceptibility to cooking (16 to 20 minutes), regardless of the $\mathrm{N}$ dose applied at common bean. After this group with greater facility for grains cooking, the materials ANFc 9, BRSMG Uai, BRSMG Madrepérola, Pérola, BRS FC402, IAC Milênio, IAC Sintonia and IPR Andorinha were classified as of normal resistance to cooking (21 to 28 minutes) and also had no influence of the $\mathrm{N}$ dose for changing the classification of susceptibility to grain cooking. The classification of BRS Estilo and IPR Curió changed from medium susceptibility to normal resistance as $\mathrm{N}$ doses increased. On the other hand, IPR Celeiro changed from normal resistance to medium susceptibility with the increment in topdressing $\mathrm{N}$ dose, although no significant difference was observed between the doses for CT (table 3). The scale of Proctor and Watts (1987) classifies the cooking resistance of grains in VS: Very susceptible, (less than 16 minutes), MS: Medium susceptibility (16 to 20 minutes), NR: Normal resistance (21 to 28 minutes), MR: Medium resistance (29 to 32 minutes), R: Resistant (33 a 36 minutes) and VR: Very resistant (more than 37 minutes). There were no common bean grains that cooked with less than 16 minutes or more than 28 minutes. 
Based on PC2, there was a direct correlation between crude protein content in the grains, TMH, FVabs and HR (0.48), although for this last-mentioned variable the score was lower than 0.60 . Moreover, it can be noted that CT has inverse correlation with these variables. However, such relationship is not very pronounced, since the score of CT with PC2 is low (-0.20). Similar results were reported by Pereira et al. (2017) and Mingotte et al. (2015), who observed inverse correlation between CT and protein content for some genotypes. However, in general, the correlations observed by these authors were not statistically significant ( $r=-0.19$ and $r=-0.22$, respectively). Farinelli and Lemos (2010) found reduction in CT as a function of increasing protein content under no-tillage system. These results suggest that cooking time is not influenced only by protein content, but also affected by other factors which depend on the genotypes, which makes it difficult to use protein content for indirect selection of cultivars with shorter cooking time. The content of total soluble solids, water absorption capacity by the grains (14), iron content in the grains $(16)$ and nitrogen fertilization $(5,18)$ also affect CT.

\section{Conclusions}

The grain quality of common bean is more dependent on the genotype studied than on agricultural management such as nitrogen fertilization. However, the increase in the $\mathrm{N}$ dose applied as topdressing increases the size of common bean grains and their protein content, but with little influence in grain hydration. The final water volume absorbed and cooking time by grains depend on the interaction between cultivar and $\mathrm{N}$ doses. Furthermore, the study of the interaction between the attributes, allows us to conclude that cooking time has a little pronounced inverse correlation with crude protein content in the grains. The cultivars BRSMG Uai, IAC Alvorada, TAA Dama and TAA Bola Cheia have the best grain technological characteristics.

\section{REFERENCES}

1. Amaral, C. B.; Pinto, C. C.; Flôres, J. A.; Mingotte, F. L. C.; Lemos, L. B.; Fornasieri Filho, D. 2016. Produtividade e qualidade do feijoeiro cultivado sobre palhadas de gramíneas e adubado com nitrogênio em plantio direto. Pesquisa Agropecuária Brasileira. 51(9): 1602-1609.

2. Association of Official Analytical Chemists (AOAC). 1995. Official methods of analysis. $16^{\circ}$ ed. Washington: AOAC. 200 p.

3. Carbonell, S. A. M.; Chiorato, A. F.; Gonçalves, J. G. R.; Perina, E. F.; Carvalho, C. R. L. 2010. Tamanho de grão comercial em cultivares de feijoeiro. Ciência Rural. 40(10): 2067-2073.

4. Companhia Nacional de Abastecimento (CONAB). 2018. Acompanhamento de safra brasileira: grãos - safra 2017/2018 Quarto levantamento. 2018. Available at: <http://www.conab.gov.br/ OlalaCMS/uploads/arquivos/18_01_11_14_17_49_graos_4o_levantamento.pdf $>$. Accessed on: Nov 122018.

5. Farinelli, R.; Lemos, L. B. 2010. Produtividade eficiência agronômica características nutricionais e tecnológicas do feijão adubado com nitrogênio em plantio direto e convencional. Bragantia. 69(1): 165-172.

6. Filla, V. A.; Prates Coelho, A.; Tiraboschi Leal, F.; Trombeta Bettiol, J. V; Borges Lemos, L. 2020. Portable chlorophyll meter in monitoring and management of nitrogen in common bean cultivars. Revista de la Facultad de Ciencias Agrarias. Universidad Nacional de Cuyo. Mendoza. Argentina. 52(2): 64-77.

7. Hair, J. F.; Black, W. C.; Babin, B. J.; Anderson, R. E.; Tatham, R. L. 2009. Data multivariate analysis. Bookman Editora. $536 \mathrm{p}$.

8. Kaiser, H. F. 1958. The varimax criterion for analytic rotation in factor analysis. Psychometrika. 23: $187-200$.

9. Miano, A. C.; Saldaña, E.; Campestrini, L. H.; Chiorato, A. F.; Augusto, P. E. D. 2018. Correlating the properties of different carioca bean cultivars (Phaseolus vulgaris) with their hydration kinetics. Food Research International. 107: 182-194.

10. Mingotte, F. L. C.; Guarnieri, C. C. O.; Farinelli, R.; Lemos, L. B. 2013. Desempenho produtivo e qualidade pós-colheita de genótipos de feijão do grupo comercial carioca cultivados na época de inverno-primavera. Bioscience Journal. 29(5): 1101-1110.

11. Oliveira, A. P.; Andrade, G. F.; Mateó, B. S. O.; Naozuka, J. 2017. Protein and metalloprotein distribution in different varieties of beans (Phaseolus vulgaris L.): Effects of cooking. International Journal of Food Science. 2017: 1-8. 
12. Pereira, H. S.; Alvares, R. C.; Melo, L. C.; Costa, A. F.; Carvalho, H. W. L. 2017. Culinary and nutritional quality of common bean lines with Carioca grain type and interaction with environments. Revista Ceres. 64(2): 159-166.

13. Perez, A. A. G.; Soratto, R. P.; Manzatto, N. P.; Souza, E. F. C. 2013. Extração e exportação de nutrientes pelo feijoeiro adubado com nitrogênio em diferentes tempos de implantação do sistema plantio direto. Revista Brasileira de Ciência do Solo. 37(5): 1276-1287.

14. Perina, E. F.; Carvalho, C. R. L.; Chiorato, A. F.; Lopes, R. L. T.; Gonçalves, J. G. R.; Carbonell, S. A. M. 2014. Technological quality of common bean grains obtained in different growing seasons. Bragantia. 73(1): 14-22.

15. Proctor, J. R.; Watts, B. M. 1987. Development of a modified Mattson Bean Cooker procedure based on sensory panel cookability evaluation. Canadian Institute of Food Science and Technology Journal. 20: 9-14.

16. Ribeiro, N. D.; Mambrin, R. B.; Storck, L.; Prigol, M.; Nogueira, C. W. 2013. Combined selection for grain yield cooking quality and minerals in the common bean. Revista Ciência Agronômica. 44(4): 869-877.

17. Rodrigues, J. A.; Ribeiro, N. D.; Londero, P. M. G.; Cargnelutti Filho, A.; Garcia, D. C. 2005. Correlação entre absorção de água e tempo de cozimento de cultivares de feijão. Ciência Rural. 35(1): 209-214.

18. Soratto, R. P.; Fernandes, A. M.; Souza, E. F. C.; Souza-Schlick, G. D. 2011. Produtividade e qualidade dos grãos de feijão em função da aplicação de nitrogênio em cobertura e via foliar. Revista Brasileira de Ciência do Solo. 35(6): 2019-2028.

\section{ACKNOWLEDGMENTS}

The authors are grateful to the Coordenação de Aperfeiçoamento de Pessoal de Nível Superior (CAPES) for granting a scholarship to the first author. 